\title{
POETIC VALUES AND POETIC TECHNIQUE IN ARISTOPHANES
}

\author{
Leslie Collins Edwards
}

At Wasps 57-66, Aristophanes distinguishes his comedy from humor of the vulgar (phortikē) Megarian sort. Elsewhere he boasts that his comedy is more intellectual, for it is clever and wise (Clouds 548, 522); and alleges that his rivals write comedy which aims only at laughs and relies for this purpose on vulgar props and language, while his comedy is primarily verbal (epea, Clouds 544), conceptual (ideai, dianoiai, Clouds 547; Peace 750; etc.), innovative (kainon ti, Wasps 1044, 1053; Clouds 547), and infused with modesty (sōphrosunè, Knights 545, Clouds 537; etc.). It goes without saying that any and all of these claims, made within a comedy, ought not to be taken entirely innocently. Nor, however, ought they to be dismissed as mere nonsense, for they contain what is an important contradiction within the logic of the dialectic between old and new so fundamental to comedy; ${ }^{1}$ it is a contradiction which runs throughout Aristophanes' discussion of his comedy, yet which is encapsulated in the first parabasis of Clouds. ${ }^{2}$ Here the poet identifies with the avant-garde; yet his poetry is modest (sōphrön) and he scorns the manners - the hairstyle, to be exact (ou komō, 545) - of the affected or decadent young of his day, although a sign of being refined (kompsos). ${ }^{3}$ Aristophanes in his posture of innovator shows impatience with the traditional inasmuch as it is repetitive; yet he also claims a position of priority and moral sensibility incompatible with the posture of innovator within the terms of his own comedy. Moreover, Aristophanes situates the antithesis between old and new within an overt hierarchy in which the old, although preferred for its moral authority, is continually being usurped by the new: sophistic rhetoric has appropriated the vocabulary which both sides of the opposition must employ and has, by controlling the terms and context, informed the debate between them.

Our consideration of this contradiction in Aristophanes' poetics will begin with the parabasis of Clouds. The oppositions he draws here in order to define his comedy in contrast with other comedy (verbal vs. physical, innovative vs. redundant, chaste vs. degenerate) not only are repeated in his other comedies but are also the basic ones informing the debate (agōn) between Aeschylus and Euripides in Frogs as well as that between the two Logoi in Clouds; we shall turn to these in the second section of this paper. The agōn of Frogs is over which poet is to be judged wiser (sophöteros), much as Aristophanes argues to be judged wisest in his parabases; in the final analysis the debate, between Aeschylus and Euripides as between Aristophanes and his rivals, reflects the problematic status of sophia at this point in the fifth century. Aristophanes confronts the contradiction in his 


\section{LESLIE COLLINS EDWARDS}

own poetics through these debates; the fact that they have different outcomes is perhaps of some significance in underscoring the complexity of his relationship to the poetics being debated; but of greater significance is the fact that in each debate one side does prevail. ${ }^{4}$

That Aristophanes' comedy is primarily verbal and chaste is argued at some length in the parabasis of Clouds (528-59):

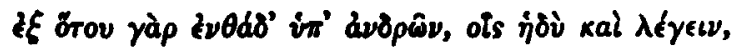

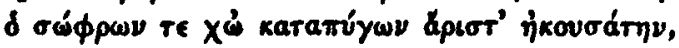

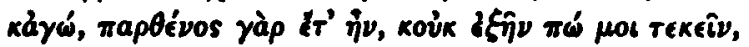

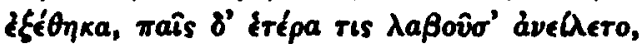

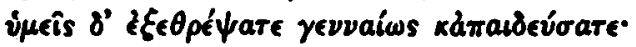

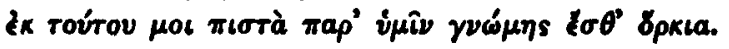

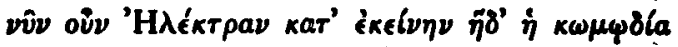

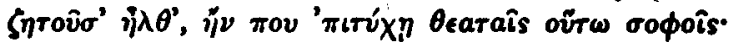

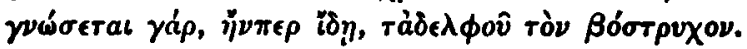

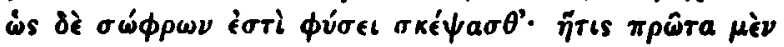

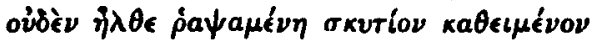

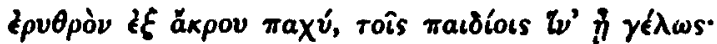

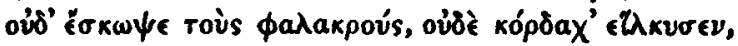

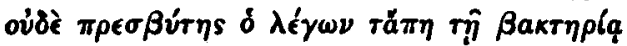

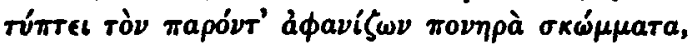

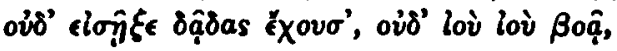

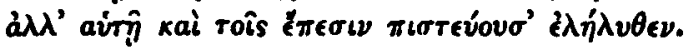

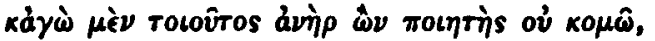

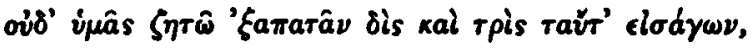

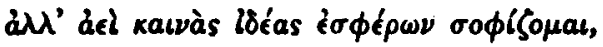

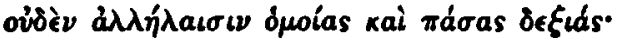

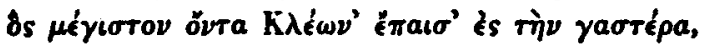

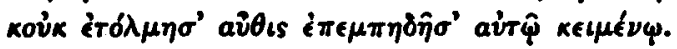

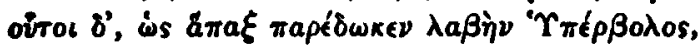

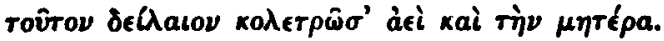

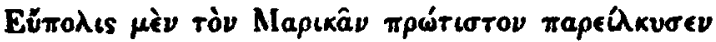

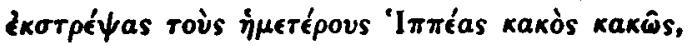

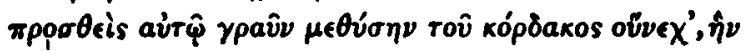

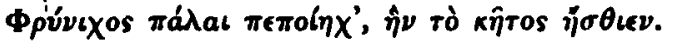

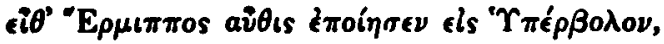
\&uor $\tau$ '

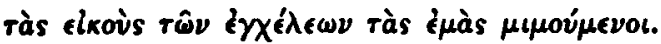

For ever since my virtuous boy and my buggered boy were excellently spoken of here by men whom it is a pleasure to mention, and I - for it wasn't proper for me, a maiden, 
to give birth - exposed the baby, and another girl picked it up, and you graciously nurtured and educated it - since then I have held faithful pledges of your good opinion. Now, therefore, this comedy, like that Electra, has come seeking to find an audience just as wise; for she'll recognize, if she looks, her brother's lock of hair. See how modest she is by nature! First, she hasn't come with a dangling bit of stitched leather, red at the end, and thick, to give children a laugh; nor does she make jokes about bald men, nor dance salaciously, nor does an old man - the one with the leading part - beat whoever is there with his stick in order to conceal foul jokes, nor does my comedy dart on-stage with torches, nor shriek 'help! help!'; but she has come trusting in herself and in her words. And I, being a poet of the same stamp, do not put on airs, nor do I seek to trick you by presenting the same plays over and over again, but I practice the poetic art always presenting new ideas, no one like the others but all of them clever. I punched Cleon in the stomach when he was at the height of power, nor did I stoop to stomp on him again when he was down. But my rivals, ever since Hyperbolus let them get a grip on him, haven't stopped trampling on him and his mother. First Eupolis hauled his Maricas on stage, shamelessly distorting my Knights, introducing a drunken old woman for the sake of her lewd dancing - the hag Phrynichus presented years ago, whom the sea-monster ate. Then once again Hermippus wrote about Hyperbolus, and now everyone else is slamming Hyperbolus, imitating my image of the eels..$^{5}$

Aristophanes claims here that he never repeats himself but produces only 'brand new ideas' (kainas ideas, 547). ${ }^{6}$ Such intellectual originality, he declares, sets him apart from the humor of comedy in general, which he alleges to be not only more physical and scatological, but hackneyed and derivative as well. Other poets merely reproduce Aristophanes' best efforts, adding only hackneyed obscenities and gratuitous physical abuse. Thus Eupolis 'distorted' (ekstrepsas, 554) Knights, adding only a drunken hag a creation long ago of Phrynichus - doing the kordax, a comic dance now trite as well as obscene; Eupolis passed this concoction off as his own Maricas. Likewise Aristophanes' rivals, in their attacks on Hyperbolus, repeatedly 'imitated' (mimoumenoi, 559) Aristophanes' image of the eels.7 Such stock features of comedy as the kordax, the phallus, beating and noise serve only 'to arouse the laughter of the immature' (tois paidiois hin' èi gelös, 539) and 'conceal the poverty of comic language' (aphanizön ponèra skömmata, 542).

Thus Aristophanes declares his artistic independence from comic precedents and tradition, and from the genre of comedy insofar as it is defined 
by such stock features and by laughter. His plays rely solely on their own language (hautēi kai tois epesin pisteuous' elèluthen, 'she has come trusting in herself and in her words', 544). Here in Clouds' parabasis, Aristophanes links together notions of the verbal, the intellectual and the innovative, to define and praise his own comedy. Yet, as we have noted, the contradiction inherent in his posture is contained here as well: as he elaborates on the sōphrosune of his comedy, he aligns himself with traditional values which are at odds with the clever originality he also claims.

Similarly, Aristophanes treats the serious moral nature of his art as if it were a logical corollary to its intellectual subtlety, even though these two values are in tension within the overall framework of his plays. His high moralism, requiring as it does restraint in addition to originality, is a sort of subset of sōphrosunè. For example, Aristophanes' attack on Cleon is heroic and pure, not opportunistic, vulgar and excessive, as are other comics' attacks on public figures: Aristophanes' battle with Cleon is like a wrestling match between two strong men. While other poets are not above trampling a conquered man - and even his mother - Aristophanes disdains to do so. As at 559, Aristophanes is the model for his rivals to imitate: their attacks on Hyperbolus are inferior copies of his original, discreet attack on Cleon. ${ }^{8}$ Yet such a way of phrasing the motivating values of his art threaten its comic credentials. So this 'feminine' play is 'modest by nature' (sōphrōn ... phusei, 537), and even has a 'feminine' author, as Aristophanes speaks of himself in the earlier stages of his career as a 'maiden' (parthenos, 530) who could not give birth or rear a baby openly, with reference to his production of plays under others' names. Clouds is like the tragic character Electra, the play hoping for victory as Electra longed for the return of her brother, her reinstatement and the end to her humiliation (534-36). ${ }^{9}$ By contrast, the rival poems are personified as male, dressed up in leather phalloi and arousing laughter (gelos, 537-39). ${ }^{10}$ As he attempts to draw the distinction between chaste comedy and licentious 'Megarian' comedy, Aristophanes' sōphrön posture has him momentarily identified with tragedy, while his rivals with their phalloi are the essence of comedy. Exaggerated though this depiction of the rivalry is, it does anticipate the agön between Aeschylus and Euripides in Frogs, where Aeschylus is identified with serious moral purpose and Euripides with intellectual subtlety, innovation and buffoonery. Moreover, it suggests the problematic nature of Aristophanes' poetics for a comic poet.

Aristophanes argues that he ought to be judged sophotatos, then, because of the political and social value of his comedy, as well as its intellectual subtlety and novelty, qualities in tension within a broader framework but which for Aristophanes are predicated on sōphrosunè. It is gelōs, defined as vulgar and personal laughter, to which these Aristophanic qualities are all opposed and which organizes Aristophanes' linking them in his poetics. After the description of the fixtures of the comic mode used by his rivals, the first parabasis of Clouds proceeds as follows (560-62): 


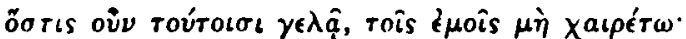

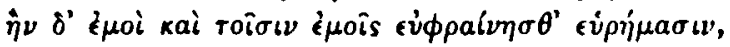

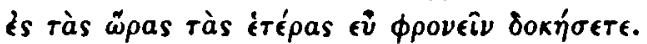

Whoever laughs at these, may he not take pleasure in my comedy; but if you are gladdened by me and my innovations, you will seem to future generations to have good judgment.

In contrast to the gelōs aroused by other comedies, a liking for Aristophanes' 'inventions' is an intellectual 'good judgment' (eu phronein, 562) made by hoi sophoi (cf. 535) and ensuring a reputation for cleverness. Aristophanes' comedy gives not primarily laughter to its audience, but kharis, a different grade of happiness." In similar terms the parabasis of Peace asks the Athenians to return 'favor' (kharis) in exchange for the 'gladness' (euphrosunē) Aristophanes has given them with his proper comedy (760-64).

Aristophanes' comedy clearly is within the traditions of its genre, replete with the obscenity and violence the poet, no doubt with some irony, rejects. Yet his argument for the superiority of his poetry does set it apart ethically and technically from other comedy in terms which virtually place it in a separate genre - one which he originated and defines. Aristophanes separates his art from comedy both generically, for Aristophanes declares his transcendence of vulgar comic traditions, and qualitatively, for his comedy's chief effect is not laughter but felicity (eudaimonia) on a political and social level. ${ }^{12}$ Within the logic of Aristophanic diction, gelos is opposite to sophia and earnestness; it is, as we have already seen, in tension with the intellectuality and moral restraint (gnōmē and sōphrosunēe) which set Aristophanes' comedy off from his rivals'. It is at several points claimed that Aristophanes is above the vulgar comic gags which arouse laughter (e.g., Wealth 799; Lys. 1218; Frogs $6 \mathrm{ff}$.); and offers nothing to the lover of buffoonery. Humor is even a symptom of the degeneracy of the ethos of the Lesser Argument ${ }^{13}$ or of Euripides, whose poetry has engendered a society of laughable buffoons. ${ }^{14}$ In Poverty's eyes, it is part of the ethos of Wealth who 'makes jokes and comedy heedless of anything earnest' (skōptein peirai kai komōidein tou spoudazein amelèsas, Wealth 557). While Aristophanes' comedy teaches ta dikaia, humor is a means for circumventing justice and reason, and a vehicle for falsity (Wasps 566f.). The sophisticated verbal wit which Aristophanes claims as his type of humor is not usually denoted by gelos (e.g. Peace 750). Still, gelōs is a component of felicity (eudaimonia) - which he does boast as a product of his poetry - as pictured in the ideal state, along with peace, fertility and youth, as well as both the tragic lyrics of Sophocles and the versicles of Euripides (Birds 732f.; Peace 339, 530-32, 540, 600). The chorus of Mystae in Frogs pray for victory for this play through its proper balance of the comic and the serious (polla men geloia m' eipein, polla de spoudaia, 'let me say much that is laughable, yet much that is serious', Frogs 391f. ${ }^{15}$ ). Similarly, the chorus of Ecclesiazusae are confident of victory because it 
appeals to lovers both of sophia and of gelōs (1154-57). Aristophanes' comedy strives in theory for gelos which is sōphrōn, bracketed by a serious purpose; his plays offer on-stage an exemplary, balanced world in which neither solemnity nor humor is practised immoderately but in which this 'balance' is moderated by sōphrosune.

Aristophanes' explicit alignment with sōphrosunè depends on his definition of his poetry in terms of the opposition between the physical and the verbal, and his identification with the latter. But this simple structure is not the whole story: his poetry discloses not only the vulgar physical gimmicks of comedy but also verbal, rhetorical tricks: it is the destructive language of Cleon that Aristophanes sees himself as battling at Peace 758. In Acharnians the chorus explain the benefits of Aristophanes' satire to the Athenians (630-40):

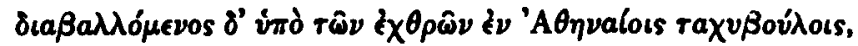

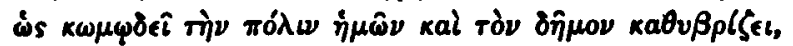

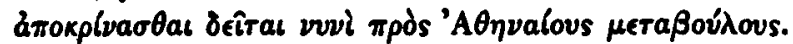

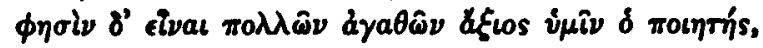

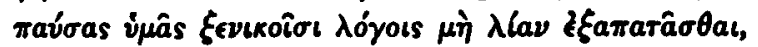

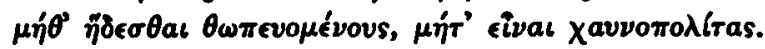

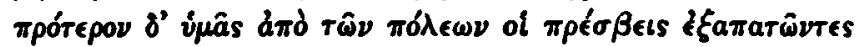

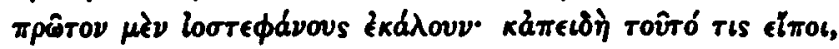

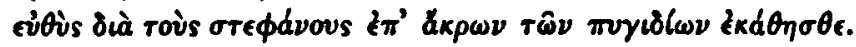

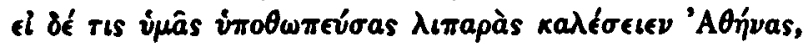

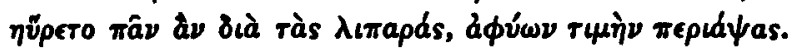

Having been slandered by his enemies among the quickto-judge Athenians for making comedies about the city and for insulting its people, he now must make a reply before these changeable Athenians. The poet says that he deserves many good things from you, for having prevented you from being too much deceived by foreign words, from getting pleasure out of flattery, from becoming gullible citizens. Before when the ambassadors from allied cities were trying to trick you, they called you 'violet-crowned'. Then whenever somebody said that, you sat on the edge of your little butts because of that crown. Then if someone would call Athens 'shiny' in order to flatter, he'd get anything from you for honoring you with an epithet for anchovies.

Aristophanes protects the Athenians from being tricked or flattered by 'unfamiliar/foreign words'. What exactly these xenikoi logoi for which Aristophanes' poetry is the antidote are has been much discussed, ${ }^{16}$ but it seems most probable that Aristophanes is purporting here to expose language which departs from reality - excessive, inflated and irrelevant language 
- for the trickery it is. Such language threatens to make the Athenians worse, not better, citizens. Liparos (639), which has in the earlier poets a more elevated sense ('gleaming'), is not - now that it means 'shiny' and evokes anchovies - suited to describing a city. Iostephanos ('violet-crowned', 637), with its Pindaric elegance, is also unsuitable: it is pure flattery and trickery, and the Athenians have, in the past, been taken in. But Aristophanes' language does not deceive because it contains only 'what is just' (ta dikaia, 645) and accomplishes real benefits for the city, inspiring the allies to visit and pay tribute (642-45). ${ }^{17}$ So also the objects of Aristophanes' moralistic aim at Knights 509-11 are the likes of Cleon and the sophists, whose trickery is essentially verbal, and who represent innovation albeit of a pernicious sort from a traditionalist perspective.

Thus the intellectual values, including 'innovation', are subjected to Aristophanes' comic scrutiny. Socrates and the sophistic 'think-tank' (phrontisterion) of Clouds come most readily to mind; the innovation and intellectualism with which they are associated have unarguably malignant overtones, subversive of traditional values. Just as crucially, the notion of the physical is not only associated with the redundant and the false, but is also, in its unsophistication, ethically conservative, the foil for the present day degeneracy of both the sophistic and the aristocratic (i.e., the uneducated Pheidippides) sorts: it is essentially and traditionally comic. In other words, the context and vocabulary Aristophanes builds for defining and praising his own comedy serves equally well for undermining it. With whom, then, does Aristophanes intend to align himself?

The unity of Aristophanes' comedy seems to emerge from the sōphrosune of its creator, for whom writing is a labor of a serious and burdensome sort, in contrast with the careless fun with which other, and especially older, comic poets patch together their assorted vulgar jokes and props. For example, he alleges that older comedy was written 'carelessly' (atalaipōrōs, fr. 254=265 K.-A.); Krates wrote 'without toil' (aponōs, fr. 333=347 K.-A.); and Aristophanes considers comedy-writing not foolish but 'the most difficult deed of all' (khalepótaton ergon hapantōn, Knights 516). ${ }^{18}$ Similarly, Aristophanes in fr. $253(=264 \mathrm{~K}$.-A.) boasts that he has changed comedy from a poor genre which used ragged costuming and ignoble props to a greater art. ${ }^{19}$ It is significant that the image of building an edifice which is applied to Aristophanes at Peace 749 is used of Aeschylus at Frogs 1004, where it is also suggested that Aeschylus redefined the entire tragic genre and created its present form: 'he first of the Greeks built the solemn rhyme and set tragic nonsense in order' (prötos tön Hellēnōn purgōsas rhèmata semnal kai kosmésas tragikon lèron, Frogs 1004f.). ${ }^{20}$

Not only does Aristophanes characterize himself as he does Aeschylus elsewhere - original and high-minded - but Newiger has pointed out the 
ideological preference shown by Aristophanes in the parabasis of Clouds (536) for the Aeschylean version of Electra's recognition of her brother over the rationalist Euripidean criticism of it. ${ }^{21} \mathrm{We}$ can see, in more general terms, that his art's serious and didactic nature corresponds to that of Aeschylus as compared with Euripides as they are portrayed in Frogs. Yet Aristophanes' attitude at Acharnians 633-45, where he is the purifier of a contaminated art, resembles Euripides' toward Aeschylus. This is further evidence that Aristophanes' self-definition is paradoxical - a fact which is made clear by an examination of Frogs, and in particular a consideration of the sophia each tragedian claims. The ambivalence of this sophia is at the heart of the paradox defining Aristophanes. Let us look first at the ideological affinity between Aeschylus and Aristophanes which emerges in the play; then we shall consider the ways in which Aristophanes' Euripides resembles him.

Like Aristophanes, Aeschylus holds that the best poetry communicates great ideas (megalai gnōmai kai dianoiai, 1059); it should not portray base or vulgar objects, but hide to ponerron (1178ff., 1050ff.). Thanks to Euripides, Aeschylus charges, citizens learn to practice 'trickery' (apatē) and buffoonery (1085f.; cf. 1521), while the aim of poetry ought to be the edification of the citizenry (1008ff.). ${ }^{22}$ Both Aristophanes and Aeschylus claim to produce weighty poetry, while Euripides and the rivals of Aristophanes attract the scum (766). During their debate, Aeschylus is moved by a deeply felt 'wrath' (kholos, 814), roaring and glowering like a bull or lion (804, 814); but Euripides' strategy is subtly defensive, his moves dependent upon and responsive to his predecessor's. Thus he 'wards off' (amunomenou, 820) the horse-prancing words of Aeschylus, who is the 'builder of the intellect' (phrenotektön, 820), and bridles them (phthonerous kinousa khalinous, '[tongue] moving the bridle of envy', 827). ${ }^{23}$ Aeschylus is said to 'press on forcefully', while Euripides 'wheels around' and 'cleverly resists' (ho men teinēi biaiōs, /ho d' epanastrephein dunètai kapereidesthai torōs, $1101 \mathrm{f}$;; cf. 775, 956-58);24 Aristophanes similarly charges his rivals with simply perverting his and other earlier work (Clouds 554). Aeschylus claims that he innovated artistically, distinguishing himself from the tradition established by his predecessor Phrynichus. On the contrary, as he charges, Euripides is promiscuously derivative. While Aeschylus drew from epic sources, Euripides drew from dance and other low music (1298ff.). ${ }^{25}$ Aristophanes, disdaining the low comedy of his rivals, personifies his comedy as a tragic character and claims epic poetic 'fame' (kleos) for himself, 'the best poet' (ho poiêtes ho aristos, Ach. 644-46). Euripides' muse is a 'harlot' (pornoidiōn; 1301; cf. 1325-28), as Aristophanes implies that his rivals' muses are pimps (Wasps 1026). Just as Aristophanes had accused his rivals of taking on narrowly personal subjects, so Aeschylus accuses Euripides of presenting trivial domestic scenes (Frogs 1331 ff.). Euripides himself, arguing for the educational value of his plays, names home economics as well arithmetic and speculation (logismos, skepsis, 973f.). While Aristophanes and Aeschylus share a civic 
orientation, Euripides' gods are 'private' (idiōtai, Frogs 891).

But alongside this ideological affinity between Aristophanes and the older tragedian there exists an identity of character and technique between Euripides and the comic poet. The excessive and empty language Aristophanes condemns and to which his poetry is an antidote is typical of Aeschylus, as Euripides charges: Aeschylus is an 'impostor and cheat' (alazón kai phenax, 909) who 'tricked his audience' (theatas eksēpata, 909f.) by giving them not real tragedy but only its 'facade' (proskhèma, 913), with language which was shaggy and lumbering, haphazard and incomprehensible (924-27). Euripides took over this art 'swollen' (oidousan, 940) with excessive language (939ff.), took off some of the weight and offered instead 'little words' (epullioi, 942) and chatter from books $(940-43){ }^{26}$ As Aristophanes cuts through rhetorical verbiage and jettisons comedians' gross physical jokes to speak the straight truth, Euripides whittles down the huge mass of Aeschylean language to speak 'as men really do' (anthrōpeiōs, 1058).

In fact, the Scholiast on Plato's Apology 19c (=Aristophanes fr. 471) claims that Aristophanes himself 'was satirized for making fun of Euripides, yet imitating him' (ekōmōideto epi tōi skōptein men Euripidèn mimeisthai d' auton). He seems to admit this in fr. $471(=488 \mathrm{~K}$.-A.), where he says that his pithy style is dependent to some extent on Euripides (khrōmai gar autou tou stomatos tōi stroggulöi, 'for I use his terseness of expression'), but his thought is far less vulgar (tous nous d' agoraious hètton $\bar{e}$ 'keinos poiō, 'but the thoughts I express are less drawn from the market-place than his'). We find the comparison between the two poets also in Cratinus fr. 307 ( $=342$ K.-A.): " Who are you?" might some refined [kompsos] spectator ask. Subtle-arguing, idea-pursuing, Euripidaristophanizer [hupoleptologos, gnömodiöktēs, euripidaristophanizonn].' The essential quality the two share is, according to this passage, verbal dexterity and intellectuality, perhaps to the point of oversubtlety. Leptos is particularly frequent in Clouds to refer to the sophistic thought and argument with which Euripides rather than Aeschylus is identified. In Frogs it is apparently a desirable quality for poetry, for the Chorus address the Muses as patronesses of intellects which are leptologoi (876). But it is particularly attached to Euripides (956), whose words are 'winged' (epterömenon, 1388) and in other ways 'light': 'sawdust', 'scratches of nonsense' (paraprismata, 881; skariphèsmoisi lèrōn, 1497). ${ }^{27}$ To be able to say something without its being understood is to speak kompseuripikös (Knights 18). Euripides in Frogs calls Theramenes his 'clever' student (kompsos, 967), while Aeschylus' are 'lancer-whiskered trumpeters' and 'flesh-tearing pinebenders' (salpiggologkhupēnadai, sarkasmopituokamptai, 966). ${ }^{28}$

Seen through Aeschylean eyes, such dexterous intellectuality translates into insubstantiality and contrasts with the (literal) weight (baros) of Aeschylean verse (Frogs 1365-1410). ${ }^{29}$ It is not that Aeschylean poetry has no intellectual component, but that it is of a different quality - that of greatness and bigness - as is represented through its substantial phrases (rhemata, 1367). ${ }^{30}$ Such intellectuality is not opposed to the physical, but 
its power is expressed by it. On the contrary, the ideai Aristophanes and Euripides present are 'weightless', characterized by cleverness or refinement (dexios, 71, kompsos, 1108, etc.). ${ }^{31}$ Euripides' 'slick tongue' (lisphē glössa, 826) contrasts with Aeschylus' bellowing of phrases with titanic blast, words bolted down like planks (823-25). As they fight it out in their debate, Aeschylus is the lion or bull, Euripides the faster and lighter boar; Aeschylus is the giant rooting up words like tree-trunks, Euripides works with a file (901-4) to carve his clever phrases and wit. The chatter (cf. lalountes, 917) of Euripides' characters is contrasted with the silent and veiled characters of Aeschylus ( $911 \mathrm{ff}$.). Thus also, as we saw, Aristophanes takes pride in the greater articulateness of his comedies as compared with his rivals'.

The debate between the tragedians recalls, then, the contrast between Aristophanes' morally purifying and technically innovative comedy on the one hand, and his rivals' redundant vulgarity on the other. Aristophanes has an affinity with Euripides as the bold inventor of new phrases (96ff.), and an affinity with Aeschylus as the savior of the city who improves its citizens $(1501,1530)$ and rejects idle philosophic chatter (1492-98) in favor of the great labor (ponos) which creates moral maxims. Aristophanes has this double affinity for the two tragedians in common with the play's Dionysus, who seeks and prefers Euripides when he descends to the underworld, yet judges Aeschylus sophotatos in the end. For the poet of the parabasis of Clouds, there is a crucial connection between ethical content and technical prowess - not the cleft which animates the debate in Frogs. It is the particular virtue of Aristophanes' poetry to embody this connection.

This complex relationship between Aristophanes and the two tragedians he portrays in Frogs reflects the ambivalent nature of the play's sophia: it is, after all, the claim to possess sophia which motivates both the parabasis of Clouds and the debate between Euripides and Aeschylus. As it has been widely noted, the term sophia had already been invested with ambiguity at least by the time Sophocles, in his Philoctetes, assigned it to the shrewd and thieving Odysseus and opposed it to ta dikaia ('justice').32 For Euripides the term is inherently complex, as in to sophon ou sophia (Bacchae 395), the false, intellectual 'wisdom' of Pentheus as opposed to the true 'wisdom' of the devout. Such false wisdom is closely connected with the 'clever tongue' (eutrokhos glōssa, 266ff.). The Sisyphus [DK 88 B25] makes it a man of sophia who invents the fear of the gods in order to keep men honest: he did so with a lie which hid the truth. ${ }^{33}$ Plato portrays Socrates as cognizant of the potential for sophia to mean not pure 'wisdom' but the more pragmatic 'shrewdness' which enables one to make the lesser argument appear better (Apol. 18b;20d-e). The contest for sophia necessarily implicates Aristophanes in the sophistic wisdom he disdains; and the problematic meaning of the term is at the root of some difficult passages in Frogs. ${ }^{34}$

In deciding that Aeschylus deserves to be called sophōtatos, Dionysus chooses moral maxims and judgments of social and political value (gnömai agathai, 1502; agathai epinoiai, 1530) over technical sophistication 
and aesthetic refinement. Yet the judgment is equivocal: not only does he have great difficulty deciding, but his deliberation shows a persistent appreciation for Euripides' mastery of a brand of sophia which is clever if untraditional, even as he grows to value the greater social merit of Aeschylus' $\operatorname{art}^{35}$ It is the sophia of 'refinement' (kompseia, 967f.), of 'contradictions, twists and dodges' (antilogiōn kai lugismōn kai strophōn, 775f.), which dislodges Aeschylus from the tragic chair prior to the contest and which presumably attracts Dionysus initially (66f. and 103). The elusive sense of sophia throughout the play makes it difficult to interpret two of Dionysus' final pronouncements on the contest. Having weighed their verses and found Euripides wanting, Dionysus wavers still: one is sophos but 'the other I enjoy' (tōi d' hédomai, 1413). Having solicited their advice to the state in order to find a final basis for his judgment, Dionysus comments that one poet speaks 'wisely' (sophōs), the other 'clearly' (saphōs, 1434). Since antiquity commentators have debated about which poet is to be identified as sophos here. $^{36}$ Indeed, contributing to the difficulty of assigning sophia in 1434 to one or the other playwright is that the sophia of Frogs seems to have two aspects: it comprehends both agile Euripidean intelligence and nobler traditional Aeschylean sentiment. So the chorus urge both contestants to seek to 'display their venturesome daring and subtle wit, to employ things old and new' (ta te palaia kai ta kaina,/kapokinduneueton lepton ti kai sophon legein, 1107f.), implying that sophia depends on each of these distinct areas. The language of the chorus at 1482ff. and at 1101-08 suggests that the victory of Aeschylean sophia rests on a definition of it as embracing the power of the intellect in partnership with moral judgment - rejecting the potential immorality of the Socratic logic-chopping to which Euripides is inclined ${ }^{37}$ Dionysus' position in respect to these two types of sophia is roughly that of Aristophanes' own as he depicts it: both are traditionalistic and react against sophistic or Euripidean sophia as subversive and amoral; yet both retain a technical and aesthetic affinity for this sophia of cleverness. A consideration of the debate between the two Logoi in Clouds will enable us to articulate further the way in which Aristophanes' poetics represent a synthesis of the two types of sophia..$^{38}$

The sophia of Clouds is similarly double-edged, so that the qualities Aristophanes claims for his own poetry implicate him in an antithetical ethical posture. In the parabasis, as we have seen, he explicitly identifies truth with his own art, and specifically with its verbal and intellectual orientation. Trickery, on the other hand, he associates with the devices by which comedy seduces an audience: the physical and inarticulate nature of the genre. ${ }^{39}$ Thus Aristophanes charges that his rivals' raucous humor 'obscures' (aphanizōn, 542) their lack of wit, but aphanisis is ordinarily used of the sophistic deception of the Phrontisterion or of the Weaker Argument (757ff., 972ff.). In Clouds as a whole the essential qualities of his comedy as he defines them in the parabasis - newness, inventiveness, and verbal dexterity - are associated with the Phrontisterion or the Weaker Argument and given a malignant 
force. Aristophanes' 'innovations' (heurēmata) constitute a lasting blessing to Athens (561f.); yet heurēma is used in Clouds of the products or activities of the Phrontisterion, and is the Weaker Argument's forte $(137,228,728$, 896, 1310). The Weaker Argument boasts of, or is associated with, 'novel words', 'opinions' and 'affairs' (kaina epē, gnōmai and pragmata, 896, 1397, 1399) as Aristophanes brags about his 'novel ideas' (kainai ideai, 547). Aristophanes' ideal of subtle wit and his denigration of his rivals' clumsy inarticulateness conform to the Phrontisterion ideal of subtlety and cleverness (e.g. 418, 428, 834, 1399) and echo Socrates' denunciation of Strepsiades as a rustic (628), an archaism (398), a buffoon (296f.). Strepsiades, as he enters the Phrontisterion, hopes to become 'a fabricator of lies, inventor of phrases, and legal chicaner' (pseudōn sugkollètès, heurèsiepès, peritrimma dikōn, 446f.). And he is encouraged to use his newfound inventiveness for fraudulent purposes, in order to deceive his creditors (728f.).

Finally, the agōn between the two logoi to some degree repeats, as it has been observed, ${ }^{40}$ that in Frogs between the two tragedians. The Weaker Argument is, like Euripides, associated with verbal skills (942ff., 1040), new ideas $(896,942 \mathrm{ff}$.), and degenerate sexuality (1089ff.); while the Stronger Argument argues for the value of physical culture $(985,1005 \mathrm{ff}$.), traditional poetry and music (968ff.), and sōphrosunè (962, 973ff.). Pheidippides is promised big shoulders and a small tongue should he choose to be educated by the Stronger Argument, but a big tongue and puny physique should he prefer the Weaker (1012-19). The education of old, which aimed at instilling sōphrosunē, was based on the suppression of its pupils' voices: prōton men edei paidos phōnèn gruxantos mèden' akousai ('First it was not proper for the voice of the babbling child to be heard', 963); the new education has public speaking at the center of its curriculum and views sōphrosune as an impediment to success in this arena (1055ff.). ${ }^{41}$ The Weaker Argument charges that the Stronger Argument's 'physical' curriculum will make Pheidippides into a 'pablum-eater' (blitomamman, 1001), referring to the speechlessness and simplicity of an infant. The connection between verbal dexterity and immorality is perhaps nowhere made more explicitly than in the concluding arguments of this agōn, where the two sides agree that men skilled in the verbal arts (oratory, acting, politics) are all sodomites (euruprōktoi, 1088-94).42 Finally, like Aristophanes' rivals, the Weaker Argument verges on the comic, both in his explicit ethics, which stress the pleasurable $(1073,1078)$, and in his forensic tactics. ${ }^{43}$ But like Aristophanes, the Stronger Argument teaches ta dikaia (900) and has no part in buffoonery (969); while the Weaker Argument, just as do Aristophanes' rivals and Euripides, responds and overturns (901). Yet as we continue to link this debate to Aristophanes' self-characterization, we are forced to identify him with several positions taken by the Weaker Argument, in particular innovativeness and reliance on the verbal.

Moreover, in this agōn the Weaker Argument is the victor - an outcome which is to be reversed in Frogs, where older, traditional values triumph 
in the person of Aeschylus. ${ }^{44}$ Rather, in Clouds the Stronger Argument recognizes the success of the rhetoricians and deserts to their ranks, perhaps even enrolling himself as their student. ${ }^{45}$ In this we might see him as parallel to Aristophanes, taking the paradoxical position of ethical conservatism, yet adopting progressive and innovative techniques. It is also to be noted that both Arguments are creatures of the Phrontisterion, from which they emerge at $889 \mathrm{ff}$. already engaged in an altercation. Although representing the new and avant-garde, the Phrontisterion claims mastery of both logoi: Strepsiades explains to Pheidippides that 'they say both arguments live there' (einai par' autois phasin amphō tō logō, 112), and Socrates' response to Strepsiades' request that he teach his son both arguments assumes his proficiency in both (883). ${ }^{46}$ At the end of his course in the Phrontisterion Pheidippides asks Strepsiades which argument he prefers that he use to prove the justice of sons beating their fathers (1336ff.): implicitly Pheidippides has mastered both at the school, and indeed the agōn is a form most at home in early rhetorical schools and in law courts.

Thus the rhetorical arts of the Weaker Argument, of Euripides, appear to be the means by which the traditional posture taken by Aeschylus, the Stronger Argument or Aristophanes is forced to present itself. Aristophanes, as he manipulates the weapons of sophistic rhetoric, expresses the paradox that rhetoric, although an 'invention' of the new and subversive of tradition, designs the format and defines the vocabulary through which traditional values, if they are to have any voice, must speak. Expressed in this new language, however, tradition itself becomes a rhetoric, like the Phrontisterion's Stronger Argument.

\section{University of California, San Diego}

\section{NOTES}

1. J.-C. Carriere (Le carnaval et la politique [Paris 1979], 4lf.) discusses in different terms the paradoxical attitude of comedy: on the one hand, critical of the present order, yet on the other hand, of excessive innovation. Athenian comedy is a genre, he argues, focused at once on an idealized past and on a present in need of regeneration. See also C.H. Whitman, Aristophanes and the Comic Hero (Cambridge, MA 1964), 119-25, and A. Sommerstein, 'Aristophanes and the Demon Poverty', CQ 34 (1984), 320f. The case for the serious expression of political positions through comedy and irony is made by G.E.M. de Ste-Croix, The Origins of the Peloponnesian War (Ithaca, N.Y. 1972), 355-71; while I am in this paper focusing on aesthetic rather than political positions, it will be clear that I reject the view taken by some scholars that, because Aristophanes is funny, nothing he says can be taken seriously (see, e.g., R. Rosen, Old Comedy and the Iambographic Tradition [Atlanta 1988], 5-7 and ch. 4 passim.) Rather, while the comic poet's positions are formulated according to the rules of his genre (that is, through humor), they still possess a serious historical dimension. See J. Henderson, 'The Demos and Comic Competition' in Nothing to Do With Dionysus?, ed. J. Winkler and F. Zeitlin (Princeton 1990), 271-313.

2. I assume that the Aristophanes whose views are expressed in this parabasis and elsewhere is a persona created by the real Aristophanes; how precisely this persona resembles its creator is, of course, an imponderable. 


\section{LESLIE COLLINS EDWARDS}

3. See K.J. Dover, Aristophanes Clouds (Oxford 1968), ad 14.

4. That Aristophanes identifies with the sophists, the objects of his condemnation in Clouds, or that he shows familiarity with their rhetorical techniques, has been noticed by several scholars, among them C.T. Murphy ('Aristophanes and the Art of Rhetoric', HSCP 49 [1938], 69-113, who sees Aristophanes as informed by the Zeitgeist, yet critical of the abuse of rhetoric by democratic politicians. J.E. Rivers ('Rhetoric and Irony in Aristophanes' Clouds' in Hypatia: Essays in Classics, Comparative Literature and Philosophy Presented to Hazel E. Barnes on her Seventieth Birthday, ed. W. Calder, U. Goldsmith, P. Kenevan [Boulder 1985], 169-85) notes the adherence of Clouds' parabasis to formal sophistic rhetorical structure (prooimion, diegesis, etc.) and concludes that Aristophanes is engaging in self-satire. See also Whitman ( $n .1$ above), 124, who sees Aristophanes as 'playing both ends of these antinomies ... against each other, till both are attenuated and reduced to absurdity'. Insightful as these analyses are, Aristophanes can be identified with a more precise and positive position than they suggest.

5. In translating the OCT text of Aristophanes I have consulted in particular A.H. Sommerstein's editions of Clouds (Chicago 1982), Peace (Chicago 1985), Acharnians (Chicago 1980), Knights (Warminster 1981), Wasps (Warminster 1983), and Birds (Warminster 1987).

6. Aristophanes tends to use idea to designate either the formal or the conceptual aspect of a thing as opposed to the thing itself; the word approaches in some cases 'genre' (eidos) and in others 'ideas, concepts' (epinoia, heurema, or dianoia, as at Wasps 1044). Starkie (The Clouds [Amsterdam 1966]. ad 289) compares idea at 547 to Thes. 436f., where Mikka's speech is praised for its formal or intellectual prowess (pasas d' ideas exetazei). For idea as 'genre' see Frogs 384; Birds 993, 1000; cf. eidos at Wealth 317; although Van Leeuwen's preference at Clouds 547 for the meaning 'genre' seems to rest on Hermann's emendation of the ms. eideas to the singular idean (Aristophanis Nubes [Leiden 1968]). It is significant that this term embraces what are, to us, the semantically opposing notions of form and content.

7. Such an image, applied to Cleon, appears at Knights 864ff; see Starkie (n.6 above) and Dover (n.3 above), ad loc. At fr.54, Aristophanes similarly complains that other poets have made three light cloaks from his coat. Cf. also Peace 739-60, Wasps $1044 \mathrm{ff}$.

8. But see Dover (n.3 above), ad loc., who makes it clear that Aristophanes did not leave these objects of abuse alone, either. See, e.g., Aristophanes on Hyperbolus' mother at Thes. $839 \mathrm{ff}$.

9. See Dover (n.3 above), ad loc., on this not very precise analogy. The reference is to the Electra in Aeschylus' Choephori; Newiger demonstrates Aristophanes' preference for the Aeschylean version over the Euripidean here ('Elektra in Aristophanes' Wolken', Hermes 89 [1961], 422ff.). See $n .21$ below.

10. Tragedy is personified as a sick female whom Euripides doctored at Frogs $939 \mathrm{ff}$. Thus also the ephemeral tragedian complained about in Frogs is compared to a lad (meirakullion, 89) who can only urinate on, not copulate with, his lover (tragedy: hapax prosoureesanta têi tragöidiai, 95), in contrast with the 'fertile' (gonimos, 96) poet Euripides. The 'lad's' poetry is 'fruitless babbling' (epiphullides, 92). On fertility and poetic creativity see Denniston, 'Technical Terms in Aristophanes', CQ 21 (1927), 113.

11. Cf. Wasps 1049, 1059. The synonymy of Prodicus (who is named at Clouds 361 by the chorus as the one man whose sophia outstrips Socrates') is parodied by Plato (Prot. 337c) with the example of his distinction between euphrainomai and hedomai as that between intellectual and physical pleasure. Thus Aristophanes might be making a point which would strike his audience as sophistic in flavor. Khairomai and euphraino can both be 'physical' and vulgar, but they are euphemistic expressions when they are, e.g. Clouds 1070. See Taillardat, Les images d'Aristophane (Paris 1962) $151 \mathrm{ff.}$, and J. Henderson, The Maculate Muse: Obscene Language in Attic Comedy (New Haven and London 1975), 221. Demetrius (De Elocutione, 128 and 163-72) identifies the difference between kharis and to geloion as that between pleasure (euphrainein) and laughter (168). Comedy inspires both laughter and pleasure, while tragedy produces strictly kharis (169). This kharis is of two kinds: the more lofty (meizones kai semnoteroi), and the more comical (kömikōterai, skömmasin eoikuiai) (128).

12. Aristophanes' claims fit in with G. Norwood's somewhat overstated distinction between the refined school of Crates (influenced by Epicharmus) and the lampoonist comedy of Cratinus, which was the inspiration for most Attic comedy (Greek Comedy [London 1931], 143-47). There is, in fact, considerable positive evidence to be found in the fragments to contradict Aristophanes' claims to 'innovation' as well as to moral superiority over his rivals and predecessors: see, e.g., Eupolis frs. 78, 244, Cratinus fr. 200-213 K.-A, Metagenes fr. 14, Pherecrates frs. 145, 95. See, for further discussion of the aesthetic, philosophical and political 


\section{POETIC VALUES AND POETIC TECHNIQUE IN ARISTOPHANES}

focuses of the comic fragments, Norwood, op. cit, 114-201; K.J. Dover, Aristophanic Comedy (London 1972), 214-16; A.W. Pickard-Cambridge, Dithyramb, Tragedy and Comedy (2nd ed., Oxford 1982) 137; and Carriere (n.1 above), 55-66. Also see Schol. V on Clouds 542ff. and C.T. Murphy, 'Popular Comedy in Aristophanes', AJP 93 (1972), 170ff., for examples from the Aristophanic corpus which refute his own disavowals of vulgarity; and cf. $\mathrm{n} .8$ above.

13. Clouds 908-10, 969: anaiskhuntos, bömolokhos, 992: skōptēi; 1078: gelōs as the key to getting a charge of adultery against one dismissed.

14. Frogs 1521: pseudologos kai bömolokhos, 1085, 1089ff: Euripides fills the city with bomolokhoi who are always tricking the people.

15. W.B. Stanford, Aristophanes: The Frogs (Basingstoke and London 1963), ad loc., compares to this passage Plato Laws $816 \mathrm{E}$, where the relation between the comic and the serious is discussed.

16. The scholiast gives two possible translations: the one above (which is also Aristotle's usage, e.g., Rhet. 1404b36, 1405a8) and 'words of foreigners'. The words in the latter sense have been taken to refer either generally to the foreign origin of many sophists (so Murphy [n.4 above], 74) or specifically to the mission of Gorgias to secure Athenian aid against Syracuse in the Sicilian war (Starkie, The Acharnians of Aristophanes [Amsterdam 1968], ad loc.); Aristophanes is thought to have cautioned against giving such aid in Babylonians. The two senses are reconcilable, however: see B.H.G. Williams, 'The Political Mission of Gorgias to Athens in 427 B.C.', CQ 25 (1931) 52-56, who argues that Ach. 634 refers to the same brand of new-fangled words that Aristophanes attacks in Banqueters (fr. 198), and for which Gorgias stood. The context (discussion of Aristophanes' purification of language) as well as external evidence (see Starkie, ad loc.) lead me to prefer the former for purposes of translation.

17. Dicaeopolis prefaces his long speech at 497-556 with the warning that he is about to speak about public affairs in a comedy, for 'comedy also knows (oide kai) justice'. This 'also' probably suggests that tragedy is the genre to be associated with the teaching of justice: see $O$. Taplin, 'Tragedy and Trugedy,' $C Q 33$ (1983), 33 I-33. Such an interpretation of this line would also lend support to Aristophanes' claims to an affinity with tragic values, the matter to which we shall turn in the next section of this paper.

18. See also Vit. Aristoph. (Arist. test. 1 K.-A.), where Aristophanes is said to have been the first to bring comedy from its 'rambling' (planómenèn) ways to 'greater usefulness and solemnity' (to khrésimōteron kai semnoteron).

19. He may well be copying Pherecrates, who claims something similar in fr. 185 as he discusses older comic poets.

20. Cf. Sch. on Peace 749 (=fr. 94), where Pherecrates is said to have had Aeschylus claim to have built (exoikodomésas) a great art.

21. Newiger (n.9 above). Euripides' skeptical Electra does not seek her brother. Newiger notes that the contrast between the tragedians is picked up again at 1364ff., where Strepsiades describes how Pheidippides insulted his favorite Aeschylus. See P. Pucci 'Euripides Heauton Timoroumenos', TAPA 98 (1976), 365-71, for a different and subtle reading of Euripides' relationship to rationalism as revealed in the Euripidean recognition scene.

22. It is actually Euripides here articulating this view of the purpose of poetry in response to Aeschylus' query, but his response plays right into Aeschylus' hands, as Aeschylus is able to argue that Euripides' poetry does not serve this end.

23. Denniston (n.10 above), 114, discusses this image of 'bridling' as signifying artistic restraint. Stanford notices ( $\mathrm{n} .15$ above, ad loc.) that the chorus' diction in this passage is a mixture of 'epico-Aeschylean' language and sophistic terminology.

24. The metaphor here is from a cavalry maneuver, as Stanford describes it ( $\mathbf{n} .15$ above, ad loc.). However, Radermacher (Aristophanes Frösche [Vienna 1921], 301) rightly emphasizes the contrast between the straightforward violence (biaiōs) of Aeschylus, and the defensive subtlety of Euripides, epanastrephein recalling the twists and turns of 775 . Indeed toros also has connotations of cleverness. Cf. fr. $638(=682 \mathrm{~K}$.-A.), where Euripides is called 'tangle-fleeced (strepsimallos) in respect to his art.'

25. Radermacher (n.24 above), 319.

26. See n.10 above. Likewise Euripides advises Agathon that the wise man (ho sophos) abbreviates his language (en brakheilpollus . . . suntemnein logous, Thes. 177)

27. Cf. Sat. Vit. Eur. fr.8. col.2. (fr.33a Supplementum Comicum, I. ed. Demianczuk [Hi]desheim 1967]), and Radermacher (n.24 above), 349f. See also Aristophanes fr. 376=392 K.-A., where Socrates is said to write Euripides' lines. Mnesimachus is said to have used the epithet sōcratogomphos, 'patched up by Socrates', of Euripides (see Teleclides fr. 39). Denniston (n.10 


\section{LESLIE COLLINS EDWARDS}

above), 119, shows that leptos is applied to Euripides and philosophers, but not to Aeschylus and Sophocles; so also Taillardat (n.11 above, 294), argues that leptos is almost always pejorative.

28. Euripides' plan for Agathon to infiltrate the women's assembly is called by Mnesilochus kompsos and entirely in keeping with his character (Thes. $91 \mathrm{ff}$.).

29. Cf. 881, where, whereas Euripides manipulates linguistic 'sawdust chips' (paraprismata), Aeschylus is empowered with 'grand language' (rhèmata). At $821 \mathrm{ff}$., Aeschylus' language is 'horse-prancing phrases' while Euripides' is 'verbal examination' (epōn basanistria). Elsewhere the diminutives rhematia and epullia are applied to Euripides' language (Ach. 398-400, 447; Peace 532-34). Cf. the schol. ad loc., who assigns rhemata to Aeschylus, the paraprismata to Euripides - a point on which there is some uncertainty. See also Radermacher (n.24 above), 269 , who comments that rhēma is a particularly unpoetic term for word(s), but rather has the sense of 'Kraftworte'

30. Frogs 1050ff., 821, 824, 828, 854, 924, 940, 1004.

31. In connection with 'lightness', note how often Euripides is associated with 'ether' (e.g., Frogs. 892, Thes. 1068, 1099, etc.).

32. Phil. 77, 1246. Probably even the sophia at Pindar Ol. 9.38 ought to be understood as akin to the sort of impious sophia condemned at, e.g., Eur. Bacch. 203 and 395. See also Odysseus' suspicious sophia at Pindar Nem. 7.21ff. and 8.26.

33. Pseudei kalupsas tên alètheian logoi. Other relevant passages include [Aesch.] PV 94446 and 962, where a sophistes is the stealer of fire; Xenophon Mem. 1.2.46, of Alcibiades' youthful cleverness; Soph. fr. 97 Nauck, where a just soul is superior to any sophistês.

34. Contra, see Dover (n.12 above, 187, and n.3 above, ad 94) who states that sophos never carries the ambivalent connotation of 'shrewd subtlety' in Aristophanes. See B. Gladigow, 'Zum Makarismos des Weisen', Hermes 95 (1967), 422., and cf. Thes. 177, 21, 1130; Birds 934, 375, 1426, 1401; Lys. 368. It seems that in its Euripidean associations sophia does take on a sinister sense, not only in Frogs but also in Clouds: see, e.g., Frogs 968 and Clouds 763, 1207. Dover ( $\mathrm{n} .3$ above ad 148) holds the same view of dexios, although it is used in connection with Socrates' brand of intelligence (cf. also $428,834,852$ ). Surely the fact that Aristophanes uses these terms to boast of his own art does not free them of ambiguity.

35. See for a discussion of Dionysus' complex attitude R. Friedrich, 'Euripidaristophanizein and Nietzschesokratizein: Aristophanes, Nietzsche, and the Death of Tragedy', Dionysius 4 (1980), 18-20. Also see L. Strauss, Socrates and Aristophanes (New York and London 1966), 262.

36. Most commentators have taken Euripides as sophos and Aeschylus as the object of enjoyment in 1413, but in view of Aeschylus' imminent victory as sophōtatos and Dionysus' original affection for Euripides, this is not entirely certain. So Radermacher (n.24 above), 335; Van Leeuwen (Aristophanis Ranae [Leiden 1968], ad loc.) and Stanford (n.15 above), ad loc. The scholiast (v) also so identifies the references but notes that while Aristarchus took Euripides as the sophos, others said otherwise. Contra, see Dover (n.12 above), 182-86, who relates Aeschylus' image of the lion cubs (1421-33) to his sophia, while Euripides is pronounced 'clear' because of his statement at 1446ff. It is perhaps helpful to note that when the chorus of Acharnians boast of Aristophanes' efforts to rid comedy of excess verbiage they refer to the pleasure of hearing such excessive language (hèdesthai thöpeuomenous, 635). 1434 has caused even more controversy because of the fairly well-developed association of Aeschylus with unclarity (asapheia: see, e.g., 927) and Euripides with sophia. Radermacher (341) and Dover (186f.) takes 1434's sophös to refer to Aeschylus, saphös to Euripides, since 'imagery and enigmatic allusion' would be Aeschylean traits. Yet Dionysus perhaps accuses Euripides of unclarity at 1445; and the chorus only moments later, clearly thinking of Aeschylus, praise the 'sharp intellect', ordinarily associated with Euripides (xunesis ekribomenè, 1482f.: cf. Radermacher, 270 and 349). There are big problems with line assignations here: see, e.g., G. Wills, 'Aeschylus' Victory in the Frogs', AJP 90 (1969), 54-56.

37. Wills (n.36 above), 52-57, is, in my view, correct to argue that Aeschylus' victory does not issue from the advice attributed to him at 1463-65: rather, he probably refused to give advice, as 1461f. imply. More likely, Dionysus chooses Aeschylean silence and all it represents over Euripidean device. Both K.J. Reckford and C. Segal see Aeschylus' victory as having to do with the poet's greater vitality as against Euripides' sterile sophia (Reckford, Aristophanes' Old-and-New Comedy [Chapel Hill and London] 1987, 428f., and Segal, 'The Character of Dionysus and the Unity of the Frogs', HSCP 65 [1961], 226).

38. I use G.B. Walsh's term 'synthesis' for what Aristophanes sees as the relevance of the dialectic between the two tragedians to his comedy, although I find it too bland to denote the position the poet is taking against sophistic ideology. Walsh, in a powerful analysis of the debate 


\section{POETIC VALUES AND POETIC TECHNIQUE IN ARISTOPHANES}

in Frogs, sees Aeschylus' poetics as grounded in a virtually materialist linguistic theory and thus irreconcilable with Euripidean aesthetic formalism (The Varieties of Enchantment: Early Greek Views of the Nature and Function of Poetry [Chapel Hill and London 1984], 85-96).

39. S. MacMathúna (Trickery in Aristophanes, Diss. Cornell 1971), 218-42, argues in detail for two types of trickery in Aristophanes - the one rhetorical and deceitful, the other physical, comic and innocent. It is with this latter type that MacMathúna sees Aristophanes as sympathetic, and I think that, on the most fundamental level, this is certainly true. But, at the same time, he explicitly identifies himself with verbal cleverness despite the deceitful connotations it clearly has at some points.

40. See Dover (n.12 above), $183 \mathrm{f}$.

41. It is interesting that the Stronger Argument's attitude towards speech seems particularly Hesiodic: the agore is, in Works and Days (29f.), the locus of immorality. Moreover, the Weaker Argument's defense of the agorètēs appeals to the authority of Homer, in particular the example of Nestor (1056f.).

42. P. Pucci ('Saggio sulle Nuvole', Maia 12 [1960], $21 \mathrm{ff}$.) discusses the deed-word (ergonlogos) opposition in this agōn, showing that söphrosune is attached to the former and wantonness (hubris) to the latter, verbal arts being valued chiefly inasmuch as they facilitate injustice. He also makes the interesting point that, contrary to traditional associations, the youth here prevails over the elder in the arena of rhetoric.

43. As Dover notes (n.3 above, lxiif.), there are two important ways in which the ethics of the Weaker Argument depart from those of the Phrontisterion: the latter are associated with neither buffoonery nor sensuality.

44. Scholars have suggested thematic reasons for the different outcomes, e.g. Reckford (n.37 above), 428; Wycherley, 'Aristophanes and Euripides', G\&R 15 (1946), 106. The most compelling reason is certainly historical: in $\mathbf{4 2 3}$ Aristophanes saw the need for a warning about the insidious influence of sophistic rhetoric on traditional civic values; in 405 , with the collapse of Athens imminent, the need was for a message of optimism.

45. See Sommerstein (n.5 above), ad $1102 \mathrm{ff}$., for discussion.

46. It would be interesting to know if, as his disappearance at 887 suggests, the Socrates actor played one of the Arguments (probably the Weaker, although both Socrates and the Stronger Argument are arguably alazones). See Dover (n.3 above), lxxvii, and K. McLeish, The Theatre of Aristophanes (New York 1980), 150. 